\title{
Effect of B20 and Low Aromatic Diesel on Transit Bus NO Emissions Over Driving Cycles with a Range of Kinetic Intensity
}

\author{
Michael P. Lammert, Robert L. McCormick, Petr Sindler and Aaron Williams \\ National Renewable Energy Laboratory
}

\begin{abstract}
The objective of this research project was to compare the emissions of oxides of nitrogen (NOx) from transit buses on as many as five different fuels and three standard transit duty cycles to establish if there is a real-world biodiesel NOx increase for transit bus duty cycles and engine calibrations. Prior studies have shown that B20 can cause a small but significant increase in NOx emissions for some engines and duty cycles. Six buses spanning engine build years 1998 to 2011 were tested on the National Renewable Energy Laboratory's Renewable Fuels and Lubricants research laboratory's heavy-duty chassis dynamometer with certification diesel, certification B20 blend, low aromatic [California Air Resources Board (CARB)] diesel, low aromatic B20 blend, and B100 fuels over the Manhattan, Orange County and UDDS test cycles. The buses selected represented the majority of the current national transit fleet as well as including hybrid and selective catalyst reduction (SCR) systems that are increasing penetration in the fleet.

The engine emissions certification level had the dominant effect on NOx, with the kinetic intensity of the tested duty cycle being the secondary driving factor. The biodiesel effect on NOx emissions was not statistically significant for most buses and duty cycles for blends with certification diesel, with the exception being a 2008 model year bus. CARB fuel had many more instances of a statistically significant effect of biodiesel increasing NOx. SCR systems proved effective at reducing NOx to near the detection limit on all duty cycles and fuels, including B100. A hybrid system proved to significantly increase NOx emissions over a same model year bus with a conventional drivetrain and the same engine. As all but one test bus were equipped with diesel particulate filter aftertreatment PM emissions were negligible and trends could not be drawn. On the oldest sample bus without aftertreatment PM emissions were reduced with B20 blends. Fuel economy was not significantly changed by engine certification level except that the 2008 conventional bus had the best performance on all cycles while all other buses had very similar results on each cycle. All buses had lower fuel economy with increased kinetic intensity of the cycle.
\end{abstract}

CITATION: Lammert, M., McCormick, R., Sindler, P. and Williams, A., "Effect of B20 and Low Aromatic Diesel on Transit Bus NOx Emissions Over Driving Cycles with a Range of Kinetic Intensity," SAE Int. J. Fuels Lubr. 5(3):2012, doi:

10.4271/2012-01-1984.

\section{INTRODUCTION}

Biodiesel is an important petroleum displacement fuel that is produced from various fats, oils, and greases. It consists of fatty acid methyl esters produced from the various feedstocks by transesterification with methanol. Biodiesel used in the United States must meet the quality requirements of ASTM Specification D6751. Over 1 billion gallons of biodiesel were produced in the United States in 2011 [1]. Typically, biodiesel is used as a blend with petroleum diesel at levels ranging from $2 \%$ to $20 \%$ by volume (B20). Energy content per gallon is slightly lower for B20, resulting in a small reduction in peak torque and fuel economy, but no change in thermal efficiency [2].
Early studies revealed that blending biodiesel into diesel fuel caused emissions of oxides of nitrogen (NOx) to increase in many engines $[\underline{2}, \underline{3}]$. It was also shown that biodiesel from unsaturated feedstocks (having more double bonds) caused a larger increase in NOx [4]. Several different hypotheses have been presented for the cause of this NOx increase [ [ ] Mueller and coworkers have shown that the primary cause is shifting of the combustion stoichiometry to be less rich at ignition and in the standing premixed autoignition zone near the flame liftoff-length [6]. However, Eckerle and coworkers demonstrated that engine control systems could respond to the lower energy content of biodiesel in ways that compensated for the NOx increase under some engine 
operating conditions [7]. Yanowitz and McCormick reviewed all available data and tried to relate differences in the effect of biodiesel on NOx to specific engines and fuel injection technologies []. They concluded that biodiesel could increase or reduce NOx emissions depending upon engine technology and driving cycle, and that there were inadequate data to determine an average effect. Transit buses represent a large niche market with a specific engine calibration. Therefore, it is important to determine if using biodiesel blends could increase emissions in this application. The objective of this research project was to evaluate the NOx emissions of a range of transit buses on as many as five different fuels and three standard transit duty cycles to establish if there is a discernible real-world biodiesel NOx increase for transit bus duty cycles and engine calibrations.

\section{BACKGROUND AND METHODS}

\section{Bus Selection}

An analysis of the 2009 American Public Transportation Association transit authority survey [9] was used to select buses to test based on the prevalence of different models in the nation's transit fleet. Figure 1 shows the population by model year of different engine makes. Beyond representing the current population, an effort was made to represent up and coming technologies such as hybrid powertrains and newer emissions control systems. While Detroit Diesel Engines used to dominate the market, in the late 1990s and early 2000s Cummins Engines began to dominate the transit bus market. Also of note is the distinct rise in hybrid powertrains starting in 2003. Table 1 breaks down the percent of the transit population represented by each engine for each engine certification period. Table 2 lists the actual buses tested to represent the biggest categories and those increasing in percent of bus population. Two Colorado transit agencies, Denver Regional Transportation District (RTD) and the Roaring Fork Transportation Authority (RFTA), loaned buses for these tests.

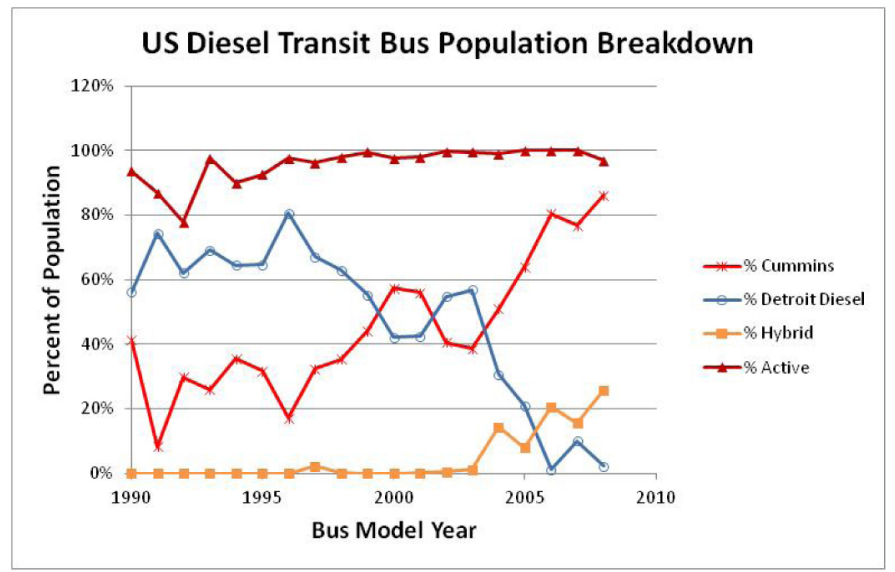

Figure 1. U.S. transit bus population.
Table 1. Population Breakdown of Current U.S. Transit Bus Fleet.

\begin{tabular}{|l|c|c|c|c|}
\hline \multicolumn{5}{|c|}{ Transit Bus Population by Emissions Model Year } \\
\hline $\begin{array}{l}\text { Model } \\
\text { Years }\end{array}$ & $\begin{array}{l}\% \text { of } \\
\text { Active } \\
\text { Fleet }\end{array}$ & $\begin{array}{l}\text { Cummins } \\
\text { Engine }\end{array}$ & $\begin{array}{l}\text { Detroit } \\
\text { Diesel } \\
\text { Engine }\end{array}$ & $\begin{array}{l}\text { Hybrid } \\
\text { Powertrain }\end{array}$ \\
\hline '98-'01 & $39 \%$ & $19 \%$ & $19 \%$ & $0 \%$ \\
\hline '02-'06 & $44 \%$ & $24 \%$ & $15 \%$ & $3.8 \%$ \\
\hline$' 07-08$ & $17 \%$ & $14 \%$ & $1 \%$ & $3.5 \%$ \\
\hline
\end{tabular}

Table 2. Selected Test Buses.

\begin{tabular}{|l|l|l|l|l|l|}
\hline \multicolumn{7}{|c|}{ Tested Transit Buses } \\
\hline $\begin{array}{l}\text { Bus } \\
\text { Model } \\
\text { Year }\end{array}$ & $\begin{array}{l}\text { Bus } \\
\text { MFR }\end{array}$ & $\begin{array}{l}\text { Engine } \\
\text { MFR }\end{array}$ & $\begin{array}{l}\text { Engine } \\
\text { Model }\end{array}$ & $\begin{array}{l}\text { Emissions } \\
\text { Equipment }\end{array}$ & $\begin{array}{l}\text { Transit } \\
\text { Agency }\end{array}$ \\
\hline 1998 & Neoplan & $\begin{array}{l}\text { Detroit } \\
\text { Diesel }\end{array}$ & $\begin{array}{l}\text { Series } \\
50\end{array}$ & none & RFTA \\
\hline 2005 & Gillig & Cummins & ISM & $\begin{array}{l}\text { EGR, } \\
\text { aftermarket } \\
\text { DPF }\end{array}$ & RTD \\
\hline 2008 & Gillig & Cummins & ISL & EGR, DPF & RTD \\
\hline 2008 & Gillig & Cummins & ISL & $\begin{array}{l}\text { EGR, DPF } \\
\text { (Hybrid) }\end{array}$ & RTD \\
\hline 2010 & Gillig & Cummins & ISL & $\begin{array}{l}\text { EGR, DPF, } \\
\text { SCR }\end{array}$ & RFTA \\
\hline 2011 & Gillig & Cummins & ISL & $\begin{array}{l}\text { EGR, DPF, } \\
\text { SCR }\end{array}$ & RFTA \\
\hline
\end{tabular}

$\mathrm{DPF}=$ diesel particulate filter, EGR = exhaust gas recirculation, $\mathrm{SCR}$ $=$ selective catalyst reduction

\section{Fuel Selection}

The purpose of this study was to identify the effect on NOx emissions from different buses on different duty cycles and using different fuels. U.S. Environmental Protection Agency certification diesel, a nominally $10 \%$ aromatic Tier 2 certification diesel meeting requirements for CARB diesel, a B100 derived from soy oil, and B20 blends of each diesel with the biodiesel were used. The CARB diesel has a lower aromatic content $(8.5 \%$ vs. $29.9 \%)$ and a higher cetane number (48.7 vs. 42.5$)$ than the certification diesel and was included in addition to the certification diesel both because CARB has great interest in NOx emissions and because the low-aromatic fuel has been shown to reduce NOx emissions [10]. Additionally, early results suggested that the effect of biodiesel on NOx may be greater for lower aromatic, higher cetane diesel fuels [ $\underline{3}]$. The biodiesel was typical of soy biodiesel. Detailed fuel properties are provided in the Appendix.

\section{Test Cycle Selection}

Dynamometer test cycles representative of common U.S. transit bus usage were desired to best represent real in-use emissions. Also taken into consideration was that the cycles chosen should be common enough that data from other researchers could be compared. The Manhattan Bus (MAN), 
Orange County Transit Authority (OCTA), and Urban Dynamometer Driving Schedule (UDDS) cycles were chosen. These cycles are also being used as part of the Altoona new bus testing program at Pennsylvania State University [11]. Table 3 shows some of the representative statistics for the cycles, and Figures $2,3,4$ show the speedtime traces of the cycles. "Average speed" is the average speed over the full time a bus engine is on and is commonly used to describe transit routes while "average driven speed" does not consider zero speed time and is more indicative of the intensity of a duty cycle. Stops per mile is another metric that is commonly used to describe transit routes. The kinetic intensity metric [12] reflects the nature of energy consumption along a given drive cycle. A large kinetic intensity value corresponds to drive cycles where the energy consumed is more strongly influenced by vehicle acceleration rather than vehicle driving speed. Similarly a small kinetic intensity value corresponds to drive cycles where vehicle speed dominates acceleration with regards to energy consumption. Lower average speeds and higher kinetic intensity and stops per mile tend to indicate a duty cycle that has more aggressive transient conditions typical of a heavy traffic urban environment and typically gets lower fuel economy than duty cycles with higher average speeds and lower kinetic intensity and stops per mile. The Manhattan Bus cycle represents transit bus operating conditions in a very dense urban environment. Of the three drive cycles, it has the most stops, lowest speed, and highest kinetic intensity. The OCTA cycle represents urban transit bus operation in the Los Angeles area and is characterized by higher driving speeds and less frequent stops than the MAN cycle. The UDDS cycle has the highest operating speeds and lowest kinetic intensity. This cycle represents generic urban and suburban operating conditions for heavy-duty vehicles and is the basis for the heavy-duty engine dynamometer federal test procedure cycle.

Table 3. Selected Representative Statistics of Chosen Dynamometer Test Cycles.

\begin{tabular}{|l|c|c|c|}
\hline & MAN & OCTA & UDDS \\
\hline Cycle Time (min) & 18.2 & 31.8 & 17.7 \\
\hline Cycle Distance (mile) & 2.1 & 6.5 & 5.6 \\
\hline Avg Speed (mph) & 6.8 & 12.3 & 18.9 \\
\hline Avg Driven Speed (mph) & 10.7 & 15.7 & 28.2 \\
\hline Maximum Speed (mph) & 25.3 & 40.6 & 58.0 \\
\hline Stops per Mile & 9.7 & 4.7 & 2.5 \\
\hline Kinetic Intensity (1/mile) & 9.1 & 3.6 & 0.6 \\
\hline
\end{tabular}

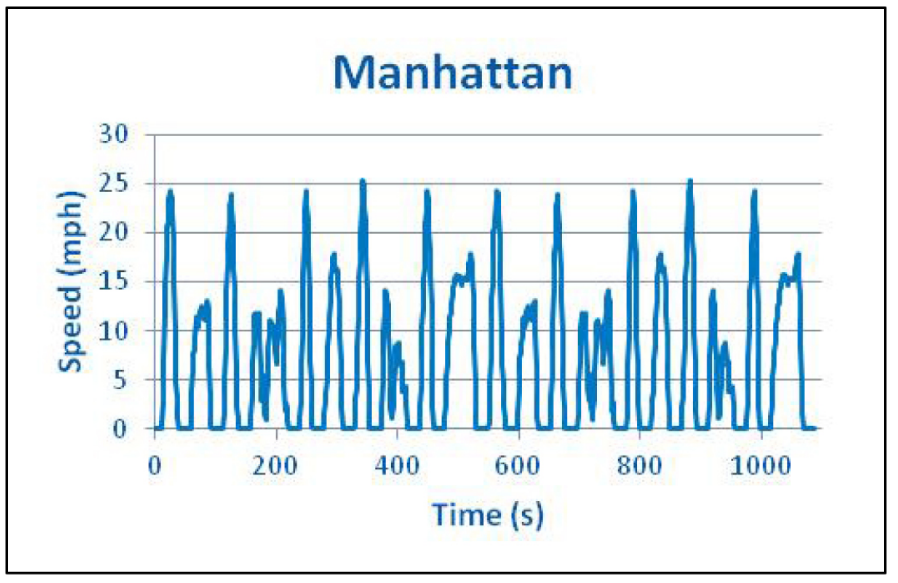

Figure 2. MAN chassis dynamometer test cycle.

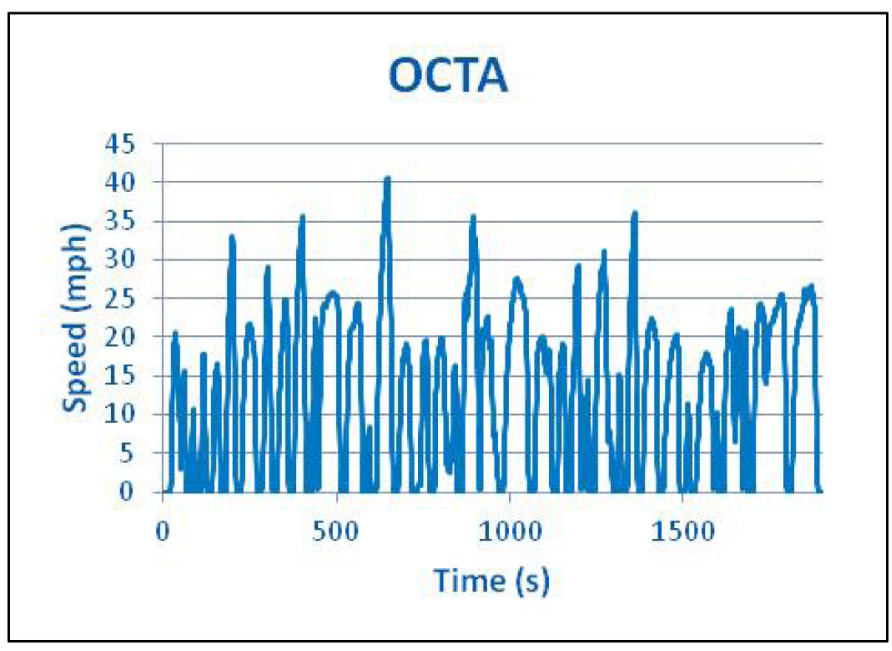

Figure 3. OCTA chassis dynamometer test cycle.

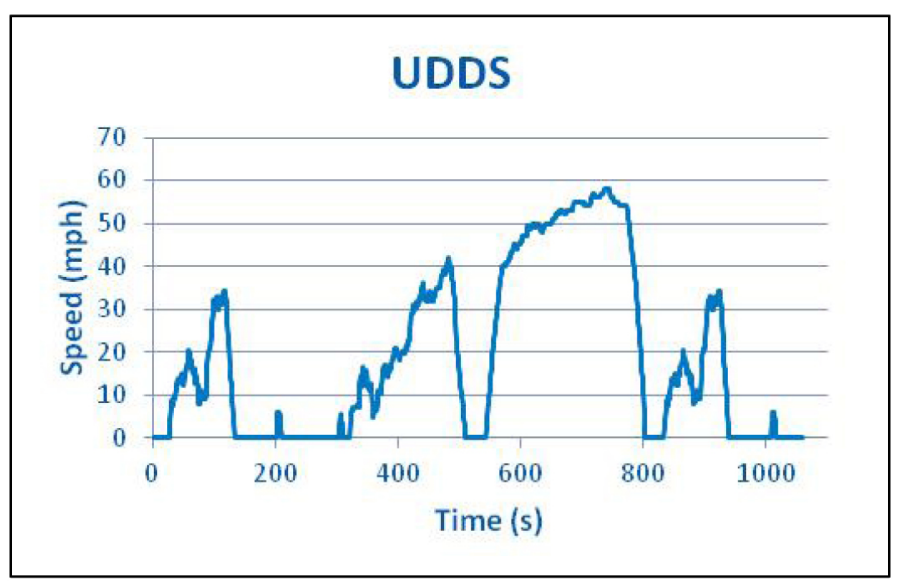

Figure 4. UDDS chassis dynamometer test cycle. 


\section{Laboratory Chassis Dynamometer Testing Procedures}

When tested, the vehicle is secured to the dynamometer with the drive axle(s) over the rollers. The vehicle is exercised by a driver following a prescribed speed trace on the test aid monitor. Test weight was determined by assuming half the rated passenger load and a driver with an average weight of $150 \mathrm{lbs}$ per person in addition to the curb weight. Vehicle weights are given in Table 4. A large fan is used to evacuate the space behind the vehicle where the hot air tends to accumulate. The engine exhaust stream is collected by the emissions measurement system for analysis, and various vehicle parameters are monitored and logged by the data acquisition system.

Table 4. Test Bus Weight.

\begin{tabular}{|l|l|l|l|}
\hline \multicolumn{1}{|c|}{ Test Bus } & $\begin{array}{l}\text { Curb } \\
\text { Weight } \\
(\mathrm{lbs})\end{array}$ & $\begin{array}{l}\text { Gross } \\
\text { Vehicle } \\
\text { Weight } \\
\text { Rating } \\
\text { (lbs) }\end{array}$ & $\begin{array}{l}\text { Test } \\
\text { Weight } \\
(\mathrm{lbs})\end{array}$ \\
\hline $\begin{array}{l}1998 \text { Neoplan / DDC Series } \\
50\end{array}$ & 30,300 & 40,600 & 33,640 \\
\hline 2005 Gillig / Cummins ISM & 28,540 & 39,600 & 31,315 \\
\hline 2008 Gillig / Cummins ISL & 27,890 & 39,600 & 30,780 \\
\hline $\begin{array}{l}\text { 2008 Gillig / Allison Hybrid } \\
\text { / Cummins ISL }\end{array}$ & 29,160 & 39,600 & 32,060 \\
\hline 2010 Gillig / Cummins ISL & 28,340 & 39,600 & 31,415 \\
\hline 2011 Gillig / Cummins ISL & 26,960 & 39,600 & 29,850 \\
\hline
\end{tabular}

To assure the accuracy and consistency of road load simulation, the dynamometer is subjected to various procedures and checks. From a practical perspective, the daily testing routine consists of following steps. In the morning the vehicle is lifted off the rollers and the dynamometer is subjected to its warm-up procedure until the parasitic loses stabilize. Then the unloaded coastdown procedure is used to verify that the parasitic loses did not change from the previous test due to component failure and that the load cell calibration has not drifted. Following this verification, the vehicle is dropped on the rollers and driven for roughly 20 minutes to warm up. After the warm-up, a conditioning test run is performed to stabilize the vehicle temperature for a given test cycle. At this point, the system is ready to either set or verify correct road load simulation through a loaded coastdown procedure. The following test runs are considered usable in terms of data validity provided the road load simulation proves consistent. This is verified after each test to ensure that changing conditions (e.g., test facility temperature) are not affecting vehicle loading. To maximize the chances of consistency, the soak period between one test end and following test start is kept at 20 minutes.

\section{Emissions measurement}

The emissions measurement system is based on recommendations in Code of Federal Regulations Section 40, Part 86, Subpart N. It consists of a full flow dilution tunnel with a constant volume sampling system for mass flow measurement. The tunnel flow rate is measured and controlled using critical flow venturis. The dilution and engine combustion air is supplied by an air handling unit that maintains the desired air temperature of $20^{\circ} \mathrm{C}$ and dew point of $12^{\circ} \mathrm{C}$.

The diluted engine exhaust was sampled for gravimetric PM analysis and by a Horiba MEXA 7100 series system for gaseous analysis including total hydrocarbons, NOx, carbon monoxide, and carbon dioxide. The gas analytical system was verified prior to the beginning of the testing period including linearization checks and NOx efficiency test. The analyzers were zero and span calibrated on a daily basis, and each test was bracketed by zero and span response reading used for corrections. The emissions measurement data were then reduced to distance-specific mass results using the Code of Federal Regulations-recommended calculations, including humidity, dry to wet, zero, span and background corrections.

\section{Fuel consumption measurement}

The fuel consumption measurement in this project relied on a gravimetric approach. The engine fuel supply and return lines were connected to a fuel container placed on a scale. The scale mass measurements were recorded in real time along with all the test data. The difference between the beginning and the end test mass measurement indicated the mass of fuel consumed during the test. Prior to testing the scale calibration was verified with a known calibration weight. The instrument used for this test was a Sartorius Midrics MAPP1U-60ED-L. The fuel consumption measurement was also backed up using the carbon balance method back-calculating the mass of fuel consumed from measurement of exhaust emissions constituents.

\section{RESULTS}

\section{Bus $\mathrm{NO}_{\mathrm{X}}$ Emissions}

\section{Neoplan / DDC series 50 NOx emissions}

A 1998 model year Neoplan 40-ft bus with a Detroit Diesel Series 50275 HP engine from RFTA was selected to represent the pre Heavy Duty Diesel Engine Consent Decree engine certification period that included no EGR or exhaust aftertreatment. Figure 5 shows the NOx g/mile results of each test cycle and fuel. Note that individual run data for NOx emissions, PM emissions, and fuel economy are provided in the Appendix. The B20 blend with certification diesel showed no statistically significant effect on NOx emissions on any cycle. The B20 blend with CARB diesel showed a 3\% to $5 \%$ increase in NOx on the OCTA and UDDS cycles, but no increase on the MAN cycle (the most kinetically intense cycle). The test cycle had a larger effect with the UDDS cycle 
producing $50 \%$ less NOx than the MAN cycle on certification diesel. The B20 blends demonstrated a $24 \%$ reduction in particulate emissions (PM) on the UDDS cycle with certification diesel and a 19-38\% reduction with CARB diesel. Figure 6 shows the PM g/mile results of each test cycle and fuel.

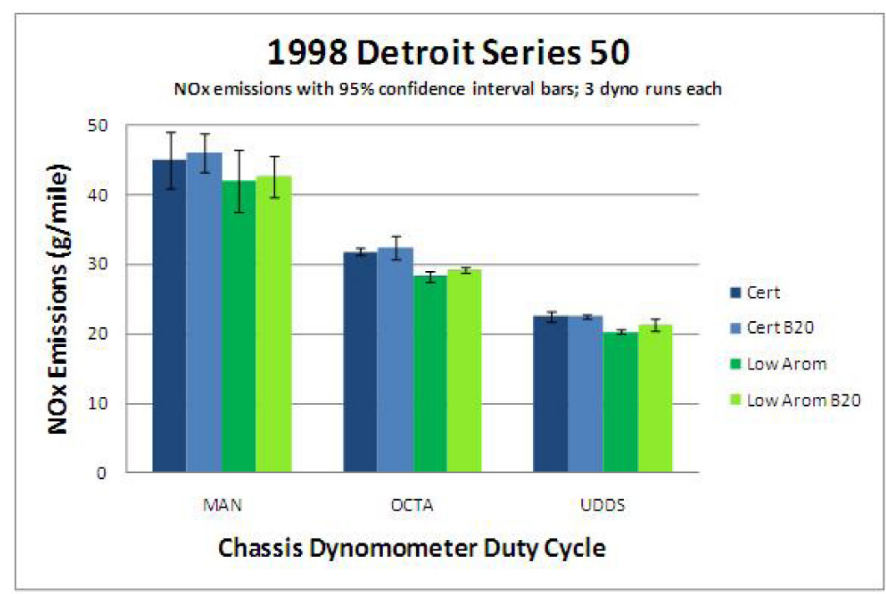

Figure 5. NOx emissions from a 1998 transit bus.

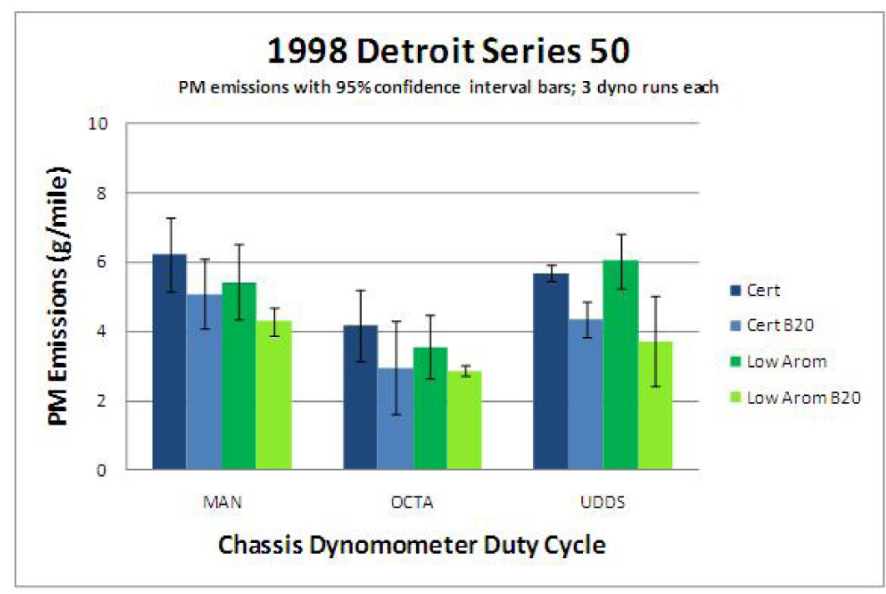

Figure 6. PM emissions from a 1998 transit bus.

\section{Gillig / Cummins ISM NOx emissions}

A 2005 model year Gillig 40-ft bus with a Cummins ISM 280 HP engine from Denver RTD was selected to represent the post Heavy Duty Diesel Engine Consent Decree engine certification period that included EGR but not DPF units. However, Denver RTD, like most transits, had installed aftermarket DPF units on its buses that did not have active regeneration, and particulate emissions were below detection limits. Figure 7 shows the NOx g/mile results of each test cycle and fuel. Note that NOx emissions for this bus were approximately $50 \%$ lower than observed for the 1998 model year bus. The B20 blend with certification diesel showed no effect on NOx for the MAN and UDDS cycles and a 5\% increase in NOx on the OCTA cycle as compared to certification diesel. The B20 blend with CARB diesel showed no increase in NOx on the MAN cycle, but a $3 \%$ to $5 \%$ increase on the OCTA and UDDS cycles as compared to CARB diesel. CARB diesel showed a $9 \%$ to $13 \%$ reduction in NOx as compared to certification diesel. The test cycle had a larger effect with the UDDS cycle producing 55\% less NOx than the MAN cycle on certification diesel.

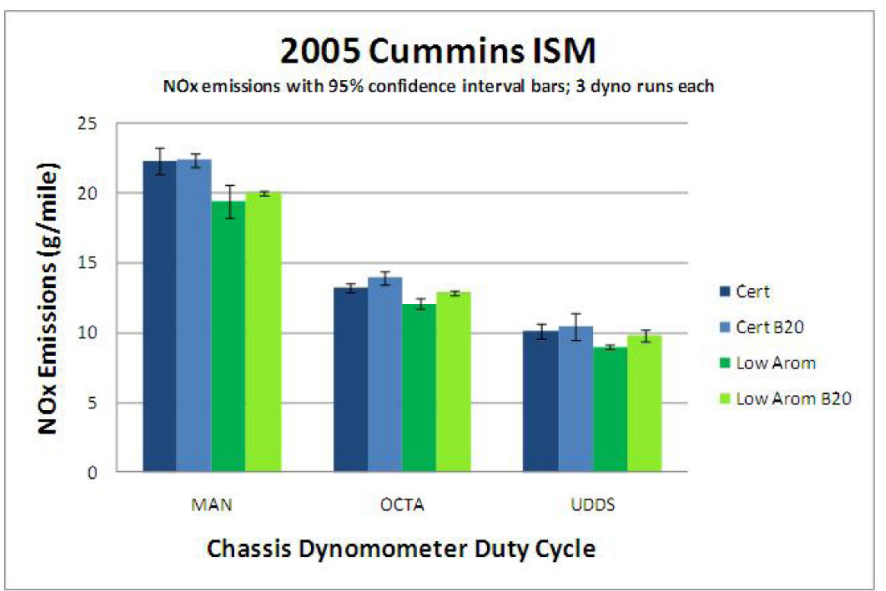

Figure 7. NOx emissions from a 2005 transit bus.

\section{Gillig / Cummins ISL NOx emissions}

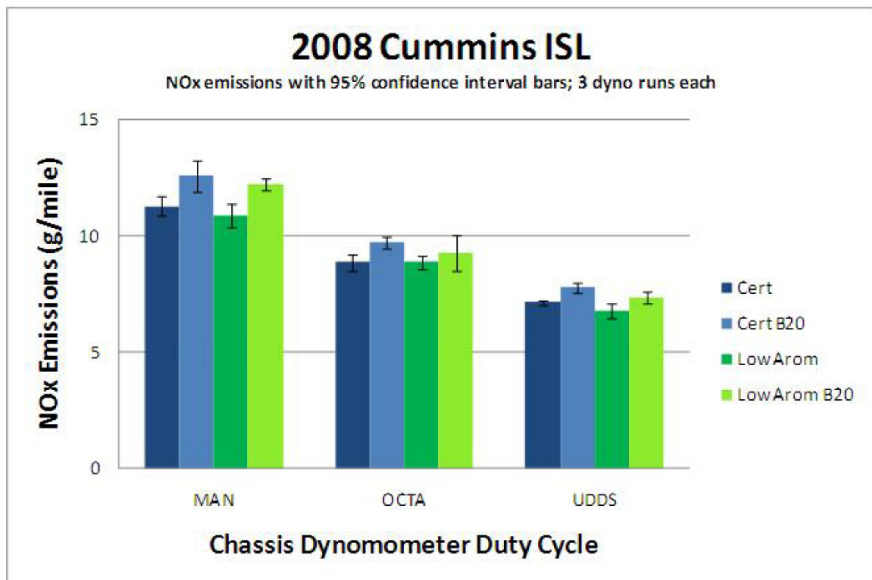

Figure 8. NOx Emissions from a 2008 transit bus.

A 2008 model year Gillig 40-ft bus with a Cummins ISL 280 HP engine from Denver RTD was selected to represent the 2007 engine certification period that included higher EGR rates and active DPF units. Figure 8 below shows the NOx g/ mile results of each test cycle and fuel. Again, note that this next vintage of emission control technology represented another approximately $50 \%$ reduction in NOx emissions compared to the 2005 model year bus. The B20 blend with certification diesel showed statistically significant NOx increases of $9 \%$ to $12 \%$ on all three test cycles as compared to certification diesel. The B20 blend with CARB diesel showed $9 \%$ and $12 \%$ NOx increases on the UDDS and MAN 
cycles, respectively, as compared to CARB diesel. Still, the test cycle had a larger affect with UDDS producing $37 \%$ less NOx than MAN on certification diesel.

\section{Gillig / Allison hybrid / Cummins ISL NOx emissions}

A 2008 model year Gillig 40-ft bus with a Cummins ISL 260 HP engine from Denver RTD was selected to represent the rapidly expanding hybrid bus segment of the population. This bus also has 2007 engine certification, including higher EGR rates and an active DPF unit. Because the relationship between certification diesel and CARB diesels had been sufficiently demonstrated, this bus was tested only on certification diesel and certification diesel B20 fuels. Figure 9 shows the NOx g/mile results of each test cycle and fuel. The B20 blend with certification diesel showed no statistically significant effect on any of the test cycles. However, it must be noted that this bus demonstrated an increase of $28 \%$ to $141 \%$ in NOx as compared to the 2008 bus with the same engine and a conventional drivetrain. The hybrid also demonstrated a stronger duty cycle effect on NOx than the conventional bus with the UDDS cycle producing $66 \%$ less NOx than the MAN cycle on certification diesel. The hybrid also had $11 \%$ to $18 \%$ worse fuel economy $(11 \%$ on MAN, $18 \%$ on OCTA, $13 \%$ on UDDS). This result was counter to expectations and to other published studies of showing that bus hybridization can significantly improve fuel economy $[13,14]$. It is unknown if there were calibration or parts failures, and the bus operator was unaware of any problems. No other issues were apparent during testing.

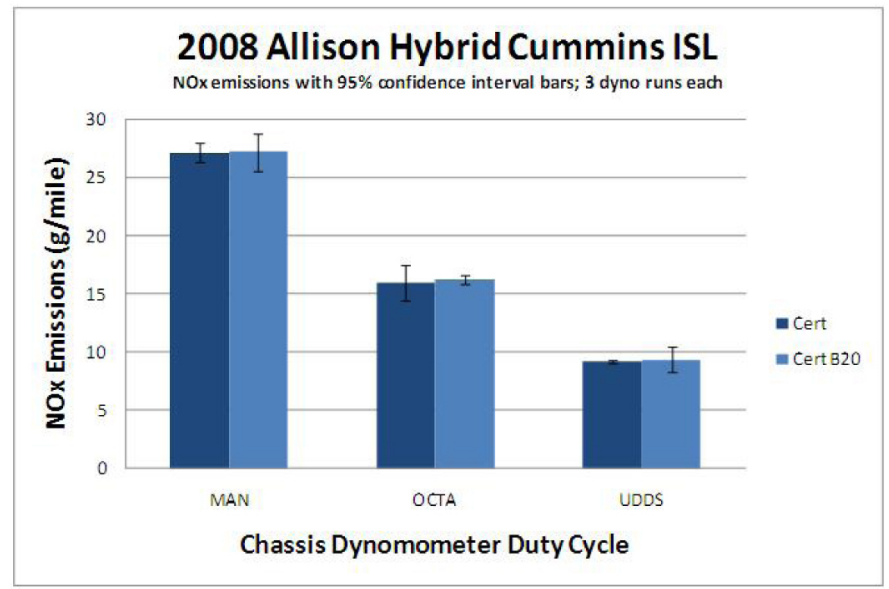

Figure 9. NOx emissions from a 2008 hybrid transit bus.

\section{Gillig / Cummins ISL (with SCR) NOx emissions}

A 2010 model year Gillig 40-ft bus with a Cummins ISL 280 HP engine from RFTA was selected to represent the 2010 engine certification period that includes SCR NOx aftertreatment in addition to DPF units. Figure 10 shows the NOx g/mile results of each test cycle and fuel. SCR aftertreatment provided the engine makers with flexibility on how to operate the engine and the ability to increase engineout NOx to improve fuel economy. B100 fuel was used on the MAN cycle to check the effectiveness of eliminating even the NOx increase from straight biodiesel. The SCR aftertreatment system was so effective that no statistically significant differences were identified among any of the fuels on the MAN and OCTA cycles. Interestingly CARB diesel demonstrated a statistically significant increase in NOx on the UDDS cycle compared to certification diesel, and a B20 blend showed a statistically significant decrease in NOx compared to CARB diesel. While statistically significant, the value of these differences were still very small. NOx emissions were on the order of $90 \%$ lower than observed for the 2008 model year (non-hybrid) bus. For much of the cycle NOx would be at or near the detection limit of the laboratory equipment, which resulted in a $95 \%$ confidence interval error that was high relative to the value of the cycle emissions.

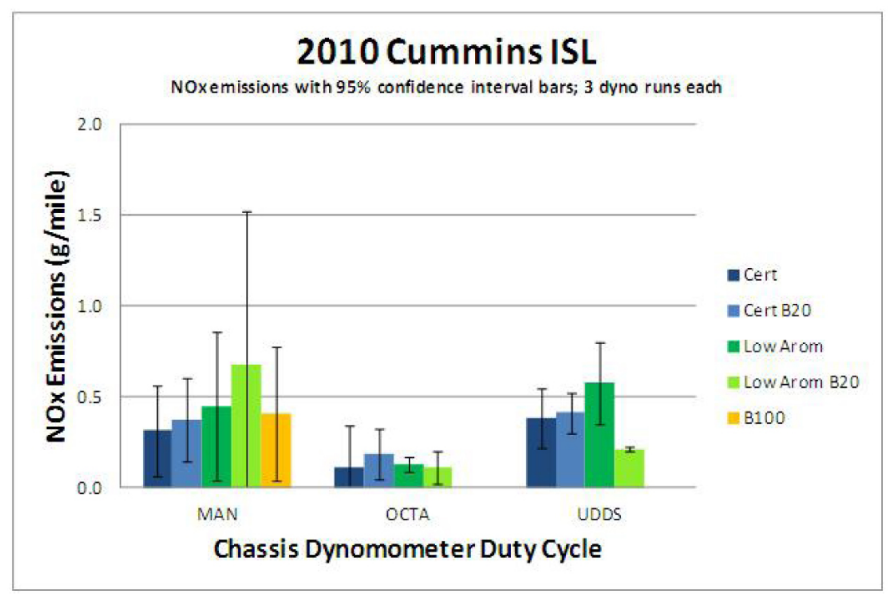

Figure 10. NOx emissions from a 2010 transit bus.

\section{Gillig / Cummins ISL (with SCR) NOx emissions}

A late 2011 model year Gillig 30-ft bus with a Cummins ISL $280 \mathrm{HP}$ engine from RFTA was selected to verify the results of the 2010 bus and to investigate the warmup or adaptation noticed during those tests. Figure 11 shows the NOx g/mile results of each test cycle and fuel. Only the MAN and UDDS cycles were tested to bracket the duty cycle spectrum, and B100 fuel was used on both cycles to investigate any prolonged adaptation by the system to eliminate even the NOx increase from straight biodiesel. The SCR aftertreatment system was so effective that the only statistically significant difference identified among any of the fuels and cycles was a reduction in NOx of $47 \%$ for B20 on the MAN cycle. For much of the cycle NOx would be at or near the detection limit of the laboratory equipment, which resulted in $95 \%$ confidence interval error that was high relative to the value of the cycle emissions. 


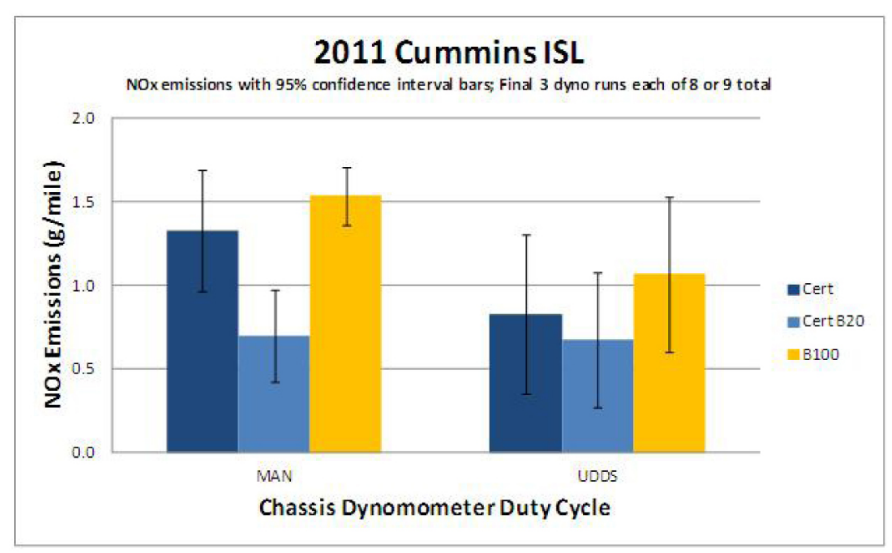

Figure 11. NOx emissions from a 2011 transit bus.

\section{SCR Warmup / adaptation behavior}

On both the 2010 and 2011 (SCR equipped) buses, achieving a repeatable $\mathrm{g} / \mathrm{mile}$ result was complicated by apparent aftertreatment warmup and/or ammonia storage behavior. It is known that copper/zeolite SCR catalysts have the ability to store significant amounts of ammonia at low temperatures. This improves the NOx conversion efficiency of the catalyst at low temperatures and simplifies urea injection strategies over highly transient conditions [15]. However, this ammonia storage can complicate catalyst testing because the NOx conversion can change as it stores or releases ammonia. Testing of the 2011 bus was adjusted specifically to investigate this behavior. A DPF regeneration was completed prior to each test campaign, causing exhaust temperature to reach over $500^{\circ} \mathrm{C}$. This high temperature event purges any stored ammonia off of the SCR catalyst [15]. Following the DPF regeneration event, the test cycle was repeated at least nine times to allow for complete stabilization of ammonia storage. The final three runs were used to calculate average hot start tailpipe $\mathrm{g} / \mathrm{mile}$ NOx emissions. This procedure was repeated for each test fuel and drive cycle. The bus was also instrumented with extra sensors: SCR temperature, pre and post SCR raw exhaust NOx emissions in addition to the dilute tailpipe NOx. Figures 12 and $\underline{13}$ show the NOx g/mile and SCR NOx conversion based on the raw exhaust results of each test cycle and fuel.

The MAN cycle showed a continued reduction of $\mathrm{g} / \mathrm{mi}$ NOx at least until the fourth hot start run on B100 and well beyond that for certification diesel and certification diesel B20. As seen in Figure 12, this steady decline in tailpipe NOx emissions is accompanied by an increase in NOx conversion. This result is likely caused by the catalyst storing increasing amounts of ammonia under the low exhaust temperature conditions created by the MAN cycle. Average catalyst temperatures for this cycle were $249^{\circ} \mathrm{C}$ for certification diesel, and peak temperatures did not exceed $284^{\circ} \mathrm{C}$. For the catalyst tested by Cavataio and coworkers [15], NOx conversion at $250^{\circ} \mathrm{C}$ more than doubled the amount of stored ammonia from $0.1 \mathrm{~g} / \mathrm{L}$ to $0.5 \mathrm{~g} / \mathrm{L}$. The UDDS cycle (Figure $\underline{13}$ ), however, showed relatively stable results on certification diesel and certification diesel B20 from the first hot run on until the end of the test campaign. This could be because the SCR catalyst temperatures are much higher with peak temperatures reaching $340^{\circ} \mathrm{C}$ to $370^{\circ} \mathrm{C}$ during the high-speed portion of the cycle. At these high temperatures, stored ammonia is much less of a factor in achieving high NOx conversion [15], so steady-state conversion is achieved much more rapidly. In addition, at $350^{\circ} \mathrm{C}$ ammonia storage should be about $50 \%$ lower than at $250^{\circ} \mathrm{C}$ [15]. On both cycles, the results for B100 proved less consistent than the other fuels, but the SCR system still kept emissions under $2 \mathrm{~g} /$ mile after the warm-up run.

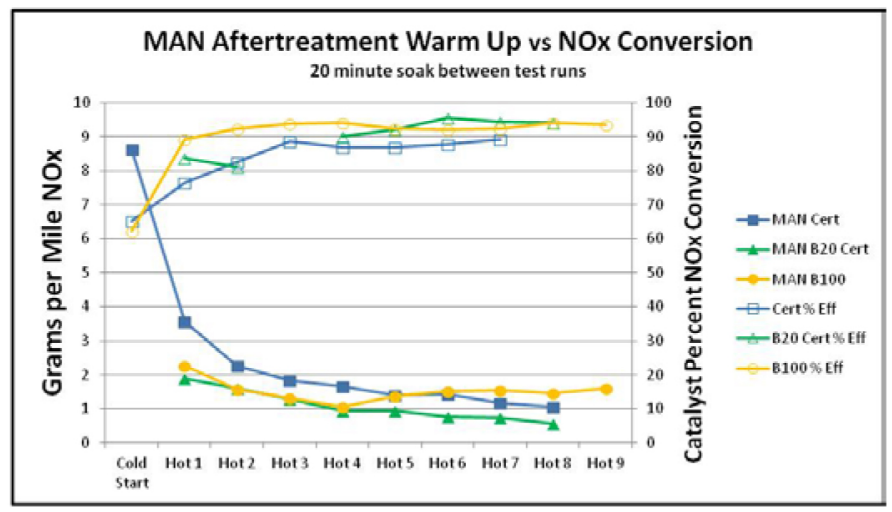

Figure 12. NOx emissions from a 2011 transit bus.

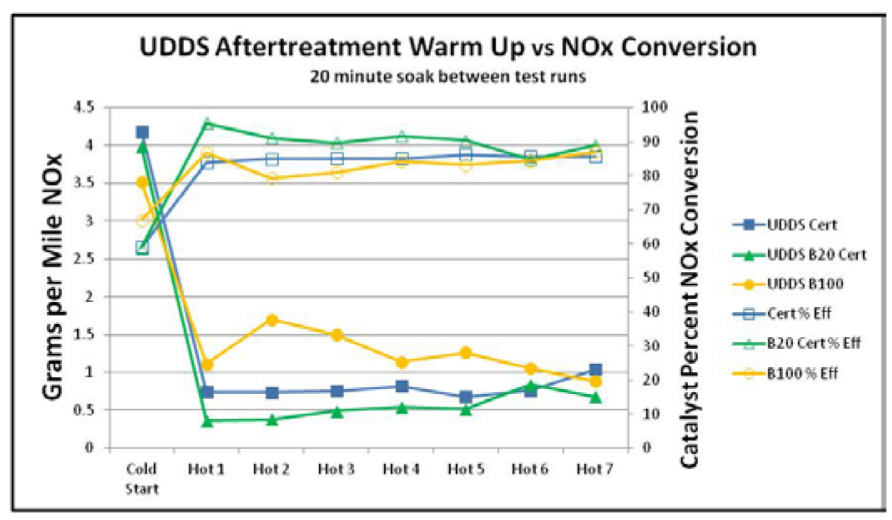

Figure 13. NOx emissions from a 2011 transit bus.

\section{Discussion}

These results show three consistent trends. First, the emissions certification level of a transit bus engine is the largest determining factor for NOx emissions. Each certification level reduced NOx emissions roughly in half from the previous certification level, and 2010 SCR NOx aftertreatment effectively reduced NOx to near detection levels at many engine operating modes. The exception is the 2008 hybrid bus, which had emissions similar to a pre-2007 bus, a possible effect of hybridization that has been observed 
before [ $[\underline{8}$. Figure 14 shows the MAN cycle NOx emissions from each bus.

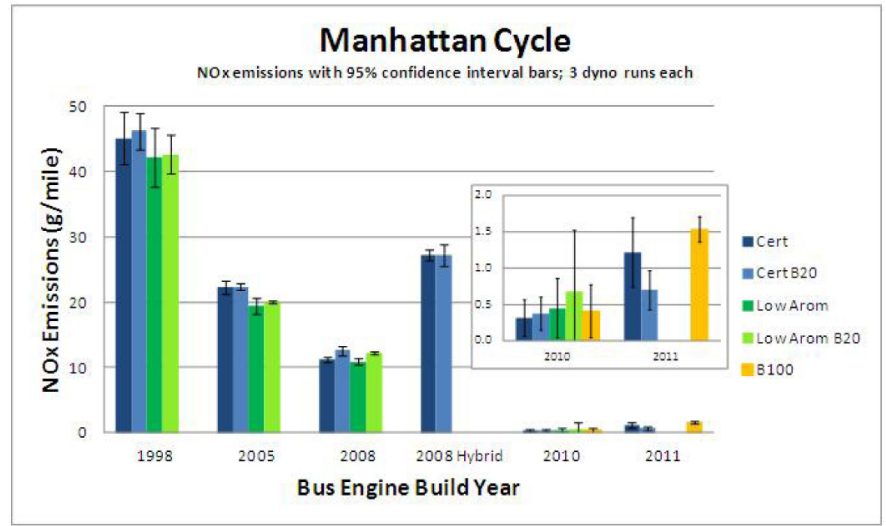

Figure 14. NOx emissions from transit buses on the Manhattan cycle.

Second, the kinetic intensity of a drive cycle determines the NOx emissions of any individual bus. All buses without NOx aftertreatment demonstrated higher NOx emissions on more intense stop and go, slow average speed, high stops per mile, and high kinetic intensity test cycles. NOx emissions on the Manhattan cycle were roughly twice that on the UDDS cycle for most buses without SCR - roughly the same change in output as an emission certification level. Figure 15 shows the NOx emissions of each test cycle of each bus by the kinetic intensity of the cycles. The engine certification level and duty cycle effects on NOx emissions are clearly evident. In every case, without NOx aftertreatment the duty cycle effect is clearly larger than the fuels effect, and most of the fuels effect is from certification diesel vs. CARB, not biodiesel content. SCR NOx aftertreatment appears to negate the effect of duty cycle and fuel on NOx emissions in transit buses.

Finally, the fuel used on each bus had a minor or not statistically significant change in NOx emissions. CARB diesel generally lowered NOx emissions while a B20 blend of either certification diesel or CARB diesel did not consistently show a statistically significant increase. The exception was the 2008 Cummins ISL, which had a statistically significant increase with B20 certification diesel on each cycle in the 9\% to $12 \%$ range. The other exception was the 2011 Cummins ISL, which had a statistically significant $47 \%$ reduction in NOx emissions with B20 (a high percentage with little realworld effect given the low baseline emissions compared to other buses in the study). SCR NOx aftertreatment appears to nearly negate the effect of fuels on NOx emissions in transit buses.

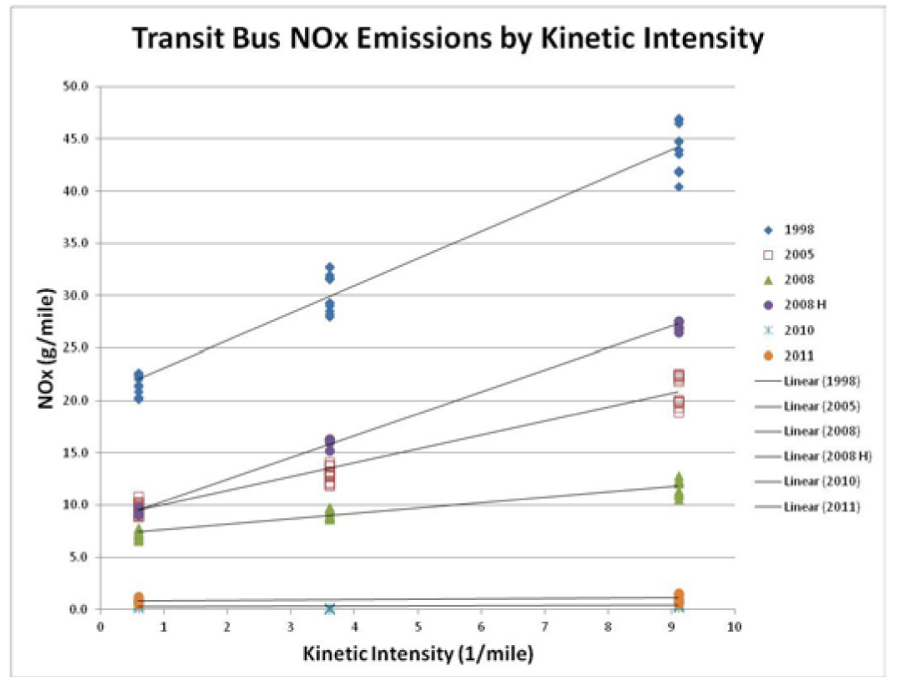

Figure 15. NOx emissions from transit buses vs. kinetic intensity.

\section{SUMMARY/CONCLUSIONS}

The choice by a transit agency to fuel its buses with a biodiesel blend has an insignificant effect on the transit's overall NOx emissions in comparison to the age of its bus fleet and the duty cycle mix of the routes it serves. Even the selection of which bus in the fleet serves the high intensity route or the lower intensity route has a far greater effect on NOx than the fuel used to power the buses. Transit bus fleets could reduce their overall NOx inventory impact by carefully matching buses to drive cycles with newer buses placed on the highest kinetic intensity routes. And, while hybrids are usually shown to save fuel, hybrids without NOx aftertreatment may have an unintended adverse effect on NOx production.

- Engine emissions certification level has the largest impact on transit bus NOx emissions.

- Route duty cycle has a very strong influence on transit NOx emissions, but is largely outside the control of a transit agency with the exception of assigning newer buses to the most kinetically intense routes.

- For buses without NOx emissions control:

- There is little or no effect of B20 on NOx for ultralow sulfur diesel.

- There is a statistically significant, but relatively small effect of B20 on NOx for CARB.

- CARB fuel consistently lowered NOx emissions on the OCTA and UDDS cycles.

- NOx emissions control appears to eliminate any fuel or duty cycle effect on NOx, even for B100.

- Result validated by testing a second SCR-equipped bus 
- Parallel hybrid drivetrain configuration can increase NOx emissions as compared to a conventional drivetrain bus of the same engine model and certification year.

\section{REFERENCES}

1. http://www.biodiesel.org/production/production-statistics. Accessed April 7, 2012

2. Graboski, M., and McCormick, R., "Combustion of Fat and Vegetable Oil Derived Fuels in Diesel Engines." Prog. Energy Combust. Sci.; Vol. 24, 1998; pp. 125-164.

3. U.S. Environmental Protection Agency, A Comprehensive Analysis of Biodiesel Impacts on Exhaust Emissions, Draft Technical Report, EPA420-P-02-001 (2002).

4. McCormick, R., Alleman, T., Graboski, M., Herring, A., and Tyson, K., "Impact Of Biodiesel Source Material and Chemical Structure on Emissions of Criteria Pollutants from a Heavy-Duty Engine," Environmental Science \& Technology 35 1742-1747 (2001).

5. McCormick, R., Ross, J., and Graboski, M., "Effect of Several Oxygenates on Regulated Emissions from Heavy-Duty Diesel Engines," Environmental Science \& Technology 31, 1144-1150 (1997).

6. Mueller, C., Boehman, A., and Martin, G., "An Experimental Investigation of the Origin of Increased NOx Emissions When Fueling a Heavy-Duty Compression-Ignition Engine with Soy Biodiesel," SAE Int. J. Fuels Lubr. 2(1):789-816, 2009, doi:10.4271/2009-01-1792.

7. Eckerle, W., Lyford-Pike, E., Stanton, D., LaPointe, L. et al., "Effects of Methyl Ester Biodiesel Blends on NOx Emissions," SAE Int. J. Fuels Lubr. 1(1):102-118, 2009, doi:10.4271/2008-01-0078.

8. Sandoval, J.A., Wayne, W.S., Posada, F., Schiavone, J., Pigman, E., Bluestone, M., Rudd, R., Stanton, H.J., Pereira, R., and D'Amore, J., "Emissions Reduction in Transit Buses: Westchester County's Proactive Approach," Journal of the Transportation Research Forum, Vol. 47, No. 3 (Public Transit Special Issue 2008), pp. 127-148 http:// www.trforum.org/journal

9. American Public Transportation Association, 2009 Public Transportation Vehicle Database, American Publication Transportation Association: Washington, DC, June (2009).

10. McCormick, R., Alvarez, J., Graboski, M., Tyson, K. et al., "Fuel Additive and Blending Approaches to Reducing NOx Emissions from Biodiesel," SAE Technical Paper 2002-01-1658, 2002, doi: $10.4271 / 2002-01-1658$

11. "Bus Testing; Phase-In of Brake Performance and Emissions Testing, and Program Updates." Federal Register 74:191 (October 5, 2009) p. 51083.

12. O'Keefe, M., Simpson, A., Kelly, K., and Pedersen, D., "Duty Cycle Characterization and Evaluation Towards Heavy Hybrid Vehicle Applications," SAE Technical Paper 2007-01-0302, 2007, doi: 10.4271/2007-01-0302

13. King County Metro Hybrid Electric Buses; http://www.nrel.gov/ vehiclesandfuels/fleettest/research hybrid king.html

14. "In-Use Performance Comparison of Hybrid Electric, CNG, and Diesel Buses at New York City Transit" http://www.nrel.gov/vehiclesandfuels/ fleettest $/ \mathrm{pdfs} / 42534 . \mathrm{pd}$

15. Cavataio, G., Girard, J., Patterson, J., Montreuil, C. et al., "Laboratory, Testing of Urea-SCR Formulations to Meet Tier 2 Bin 5 Emissions," SAE Technical Paper 2007-01-1575, 2007, doi:10.4271/2007-01-1575.

\section{CONTACT INFORMATION}

michael.lammert@nrel.gov

1617 Cole Blvd.

Golden, CO 80401

(303) 275-4067

robert.mccormick@nrel.gov

1617 Cole Blvd.

Golden, CO 80401

(303) 275-4432

petr.sindler@nrel.gov

1617 Cole Blvd.

Golden, CO 80401

(303) 275-3142 aaron.williams@nrel.gov

1617 Cole Blvd.

Golden, CO 80401

(303) 275-3153

\section{ACKNOWLEDGMENTS}

This work was supported by the U.S. Department of Energy (DOE) Vehicle Technologies Program/Clean Cities Program and would not have been possible without the generous donation of time and buses from the Denver Regional Transportation District and the Roaring Fork Transportation Authority. The authors wish to thank Dennis Smith at DOE, Lou Ha at Denver RTD, and Dan Blankenship and Kenny Osier at RFTA for their support.

\section{DEFINITIONS/ABBREVIATIONS}

B100 - 100\% biofuel

B20 - blend of $20 \%$ biodiesel and $80 \%$ petroleum-based diesel

CARB - California Air Resources Board

DPF - diesel particulate filter

EGR - exhaust gas recirculation

MAN - Manhattan Bus cycle

MFR - manufacturer

NOx - oxides of nitrogen

OCTA - Orange County Transit Authority cycle

PM - particulate matter

RFTA - Roaring Fork Transportation Authority

RTD - Regional Transportation District

SCR - selective catalyst reduction

UDDS - Urban Dynamometer Driving Schedule 


\section{APPENDIX}

Table A1. Diesel Fuel Properties.

\begin{tabular}{|c|c|c|c|c|}
\hline Property & Method & Units & CERT & CARB \\
\hline Distillation $90 \%$ & ASTM D86 & ${ }^{\circ} \mathrm{F}$ & 580 & 573 \\
\hline Gravity & ASTM D4052 & ${ }^{\circ} \mathrm{API}$ & 35.4 & 37.7 \\
\hline Specific Gravity & ASTM D4052 & & 0.848 & 0.8363 \\
\hline Flash Point & ASTM D93 & ${ }^{\circ} \mathrm{F}$ & 163 & 162 \\
\hline Cloud Point & ASTM D2500 & ${ }^{\circ} \mathrm{F}$ & -13 & -18 \\
\hline Pour point & ASTM D97 & ${ }^{\circ} \mathrm{F}$ & -22 & NA \\
\hline Viscosity, $40^{\circ} \mathrm{C}$ & ASTM D445 & $\mathrm{cSt}$ & 2.4 & 2.52 \\
\hline Sulfur & ASTM D5453 & ppm & 12 & 0 \\
\hline Carbon & ASTM D5291 & wt $\%$ & 86.79 & NA \\
\hline Hydrogen & ASTM D5291 & wt $\%$ & 13.21 & NA \\
\hline Nitrogen & ASTM D4629 & $\mathrm{ppm}$ & NA & 0.6 \\
\hline $\begin{array}{l}\text { Composition, } \\
\text { aromatics }\end{array}$ & ASTM D5186 & wt $\%$ & 29.9 & 8.5 \\
\hline $\begin{array}{l}\text { Polycyclic } \\
\text { Aromatics }\end{array}$ & ASTM D5186 & wt $\%$ & NA & $<0.5$ \\
\hline $\begin{array}{l}\text { Composition, } \\
\text { aromatics }\end{array}$ & ASTM D1319 & vol \% & 29 & NA \\
\hline $\begin{array}{l}\text { Composition, } \\
\text { olefins }\end{array}$ & ASTM D1319 & vol $\%$ & 4 & NA \\
\hline $\begin{array}{l}\text { Composition, } \\
\text { saturates }\end{array}$ & ASTM D1319 & vol \% & 67 & NA \\
\hline Cetane Number & ASTM D613 & & 42.5 & 48.7 \\
\hline Net heat content & ASTM D240 & $\mathrm{btu} / \mathrm{lb}$ & 18435 & NA \\
\hline
\end{tabular}


Table A2. B100 Properties.

\begin{tabular}{|c|c|c|c|}
\hline Property & Units & Soy B100 & D6751 limits \\
\hline Acid value & $\mathrm{mg} \mathrm{KOH} / \mathrm{g}$ & $0.24-0.35$ & $0.5 \max$ \\
\hline Rancimat & hours & $7.33-11.2$ & $3 \mathrm{~min}$ \\
\hline KF water & ppm & $264-380$ & $500 \max$ \\
\hline Free Glycerin & $\% w t$ & $0.007-0.010$ & $0.020 \max$ \\
\hline Total Glycerin & $\% w t$ & $0.105-0.126$ & $0.240 \max$ \\
\hline CSFT & seconds & $117-572$ & $360 \max$ \\
\hline $\mathrm{Ca}$ & ppm & $<0.1-0.3$ & $5 \mathrm{ppm}$ max combined $\mathrm{Ca}$ and $\mathrm{Mg}$ \\
\hline $\mathrm{Mg}$ & ppm & $<0.1$ & $5 \mathrm{ppm}$ max combined $\mathrm{Ca}$ and $\mathrm{Mg}$ \\
\hline $\mathrm{Na}$ & ppm & $<1-2.3$ & $5 \mathrm{ppm}$ max combined $\mathrm{Na}$ and $\mathrm{K}$ \\
\hline $\mathrm{K}$ & ppm & $<1$ & $5 \mathrm{ppm}$ max combined $\mathrm{Na}$ and $\mathrm{K}$ \\
\hline Flash Point & $\operatorname{deg} C$ & $137-182$ & $130 \mathrm{~min}$ \\
\hline Flash Point & $\operatorname{degF}$ & $281-361$ & \\
\hline Cloud Point & $\operatorname{deg} C$ & $-0.4--0.2$ & Report \\
\hline
\end{tabular}


Table A3. NOx Emission Results for All Tests.

\begin{tabular}{|c|c|c|c|c|c|c|c|}
\hline \multirow[b]{2}{*}{ Fuel } & \multirow[b]{2}{*}{ Cycle } & \multicolumn{6}{|c|}{ Bus Nox (g/mile) } \\
\hline & & 1998 & 2005 & 2008 & $2008 \mathrm{H}$ & 2010 & 2011 \\
\hline Cert & MAN & 43.6 & 22.6 & 11.1 & 27.0 & 0.4 & 1.4 \\
\hline Cert & MAN & 44.8 & 22.4 & 11.3 & 27.5 & 0.3 & 1.2 \\
\hline Cert & MAN & 46.9 & 21.9 & 11.4 & 27.0 & 0.2 & 1.1 \\
\hline Cert B20 & MAN & 47.0 & 22.4 & 12.5 & 26.5 & 0.5 & 0.8 \\
\hline Cert B20 & MAN & 44.9 & 22.5 & 12.9 & 27.5 & 0.4 & 0.7 \\
\hline Cert B20 & MAN & 46.5 & 22.1 & 12.4 & 27.7 & 0.3 & 0.6 \\
\hline CARB & MAN & 44.0 & 19.9 & 11.0 & & 0.6 & \\
\hline CARB & MAN & 40.5 & 18.9 & 10.6 & & 0.5 & \\
\hline CARB & MAN & 41.8 & 19.4 & 11.0 & & 0.3 & \\
\hline CARB B20 & MAN & 42.0 & 20.0 & 12.2 & & 1.0 & \\
\hline CARB B20 & MAN & 44.0 & 20.0 & 12.1 & & 0.7 & \\
\hline CARB B20 & MAN & 42.0 & 20.1 & 12.3 & & 0.3 & \\
\hline B100 & MAN & & & & & 0.5 & 1.5 \\
\hline B100 & MAN & & & & & 0.4 & 1.5 \\
\hline B100 & MAN & & & & & 0.3 & 1.6 \\
\hline Cert & OCTA & 32.0 & 13.3 & 9.0 & 16.3 & 0.0 & \\
\hline Cert & OCTA & 31.6 & 13.1 & 8.9 & 16.4 & 0.1 & \\
\hline Cert & OCTA & 31.8 & 13.3 & 8.7 & 15.3 & 0.2 & \\
\hline Cert B20 & OCTA & 32.8 & 14.1 & 9.8 & 16.3 & 0.2 & \\
\hline Cert B20 & OCTA & 32.8 & 13.9 & 9.6 & 16.3 & 0.1 & \\
\hline Cert B20 & ОСТА & 31.6 & 13.8 & 9.9 & 16.1 & 0.2 & \\
\hline CARB & OCTA & 28.6 & 12.2 & 8.9 & & 0.1 & \\
\hline CARB & ОСТА & 28.0 & 12.1 & 8.9 & & 0.1 & \\
\hline CARB & OCTA & 28.3 & 11.9 & 8.7 & & 0.1 & \\
\hline CARB B20 & OCTA & 29.4 & 12.8 & 9.0 & & 0.1 & \\
\hline CARB B20 & OCTA & 29.1 & 12.9 & 9.3 & & 0.1 & \\
\hline CARB B20 & OCTA & 29.3 & 12.9 & 9.6 & & 0.1 & \\
\hline Cert & UDDS & 22.7 & 9.9 & 7.1 & 9.2 & 0.4 & 0.7 \\
\hline Cert & UDDS & 22.7 & 10.3 & 7.2 & 9.1 & 0.4 & 0.8 \\
\hline Cert & UDDS & 22.1 & 10.2 & 7.1 & 9.2 & 0.3 & 1.0 \\
\hline Cert B20 & UDDS & 22.4 & 10.8 & 7.8 & 9.1 & 0.5 & 0.5 \\
\hline Cert B20 & UDDS & 22.5 & 10.4 & 7.7 & 9.9 & 0.4 & 0.8 \\
\hline Cert B20 & UDDS & 22.7 & 10.1 & 7.8 & 9.2 & 0.4 & 0.7 \\
\hline CARB & UDDS & 20.2 & 9.0 & 6.9 & & 0.7 & \\
\hline CARB & UDDS & 20.4 & 9.0 & 6.8 & & 0.6 & \\
\hline CARB & UDDS & 20.4 & 9.1 & 6.7 & & 0.5 & \\
\hline CARB B20 & UDDS & 21.6 & 9.6 & 7.4 & & 0.2 & \\
\hline CARB B20 & UDDS & 21.4 & 9.9 & 7.2 & & 0.2 & \\
\hline CARB B20 & UDDS & 20.9 & 9.8 & 7.5 & & 0.2 & \\
\hline B100 & UDDS & & & & & & 1.3 \\
\hline B100 & UDDS & & & & & & 1.1 \\
\hline B100 & UDDS & & & & & & 0.9 \\
\hline
\end{tabular}


Table A4. P value table for all NOx results comparisons.

\begin{tabular}{|l|l|l|l|l|l|l|l|}
\hline \multicolumn{2}{|c|}{} & \multicolumn{7}{c|}{ P value of NOx results compared to baseline } \\
\hline Fuels Compared & Cycle & $\mathbf{1 9 9 8}$ & $\mathbf{2 0 0 5}$ & $\mathbf{2 0 0 8}$ & $\mathbf{2 0 0 8 H}$ & $\mathbf{2 0 1 0}$ & $\mathbf{2 0 1 1}$ \\
\hline Cert B20 vs Cert baseline & MAN & 0.471 & 0.728 & 0.018 & 0.838 & 0.109 & 0.019 \\
\hline CARB B20 vs CARB baseline & MAN & 0.772 & 0.161 & 0.004 & & 0.173 & \\
\hline CARB vs Cert baseline & MAN & 0.221 & 0.009 & 0.153 & & 0.103 & \\
\hline B100 vs Cert baseline & MAN & & & & & 0.114 & 0.126 \\
\hline Cert B20 vs Cert baseline & OCTA & 0.282 & 0.017 & 0.019 & 0.433 & 0.409 & \\
\hline CARB B20 vs CARB baseline & OCTA & 0.006 & 0.016 & 0.216 & & 0.572 & \\
\hline CARB vs Cert baseline & OCTA & 0.000 & 0.008 & 0.872 & & 0.828 & \\
\hline Cert B20 vs Cert baseline & UDDS & 0.968 & 0.466 & 0.011 & 0.502 & 0.282 & 0.362 \\
\hline CARB B20 vs CARB baseline & UDDS & 0.059 & 0.020 & 0.035 & & 0.021 & \\
\hline CARB vs Cert baseline & UDDS & 0.011 & 0.013 & 0.047 & & 0.006 & \\
\hline B100 vs Cert baseline & UDDS & & & & & & 0.379 \\
\hline
\end{tabular}


Table A5. PM Emission Results for All Tests.

\begin{tabular}{|c|c|c|c|c|c|c|c|}
\hline \multirow[b]{2}{*}{ Fuel } & \multirow[b]{2}{*}{ Cycle } & \multicolumn{6}{|c|}{ Bus PM ( $\mathrm{g} / \mathrm{mile})$} \\
\hline & & 1998 & 2005 & 2008 & $2008 \mathrm{H}$ & 2010 & 2011 \\
\hline Cert & MAN & 6.663 & 0.003 & 0.004 & 0.003 & 0.005 & 0.006 \\
\hline Cert & MAN & 6.231 & 0.003 & 0.007 & 0.001 & 0.002 & 0.008 \\
\hline Cert & MAN & 5.807 & 0.005 & 0.004 & 0.003 & 0.004 & 0.004 \\
\hline Cert B2O & MAN & 5.055 & 0.003 & 0.004 & na & 0.010 & 0.001 \\
\hline Cert B20 & MAN & 4.697 & 0.002 & 0.004 & 0.000 & 0.026 & 0.001 \\
\hline Cert B2O & MAN & 5.506 & 0.004 & 0.003 & 0.003 & 0.012 & 0.001 \\
\hline CARB & MAN & 5.093 & 0.001 & 0.001 & & 0.008 & \\
\hline CARB & MAN & 5.916 & 0.005 & 0.005 & & -0.014 & \\
\hline CARB & MAN & 5.246 & 0.002 & 0.005 & & 0.008 & \\
\hline CARB B20 & MAN & 4.466 & 0.002 & 0.006 & & 0.014 & \\
\hline CARB B20 & MAN & 4.138 & 0.005 & 0.003 & & 0.001 & \\
\hline CARB B20 & MAN & 4.273 & 0.001 & 0.003 & & 0.001 & \\
\hline B100 & MAN & & & & & na & \\
\hline B100 & MAN & & & & & na & \\
\hline B100 & MAN & & & & & na & \\
\hline Cert & OCTA & 4.518 & 0.002 & 0.002 & 0.001 & 0.004 & \\
\hline Cert & OCTA & 4.250 & 0.001 & 0.002 & 0.000 & 0.003 & \\
\hline Cert & OCTA & 3.709 & 0.002 & 0.003 & 0.001 & 0.005 & \\
\hline Cert B20 & OCTA & na & 0.001 & 0.001 & 0.001 & 0.004 & \\
\hline Cert B2O & OCTA & 2.937 & 0.001 & 0.001 & 0.001 & 0.006 & \\
\hline Cert B20 & OCTA & 3.507 & 0.001 & 0.001 & 0.001 & 0.003 & \\
\hline CARB & OCTA & 3.570 & 0.002 & 0.002 & & 0.003 & \\
\hline CARB & OCTA & 3.915 & 0.000 & 0.001 & & 0.004 & \\
\hline CARB & OCTA & 3.174 & 0.001 & 0.001 & & 0.002 & \\
\hline CARB B20 & OCTA & 2.935 & 0.005 & 0.002 & & 0.007 & \\
\hline CARB B20 & OCTA & 2.852 & 0.001 & 0.001 & & 0.013 & \\
\hline CARB B 20 & ОСТА & 2.819 & 0.001 & 0.001 & & 0.004 & \\
\hline Cert & UDDS & 5.721 & 0.004 & 0.002 & 0.002 & 0.011 & 0.001 \\
\hline Cert & UDDS & 5.586 & 0.004 & 0.001 & 0.000 & 0.004 & 0.001 \\
\hline Cert & UDDS & 5.767 & 0.006 & 0.002 & 0.001 & 0.002 & 0.001 \\
\hline Cert B20 & UDDS & 4.413 & 0.005 & 0.001 & 0.001 & 0.002 & 0.001 \\
\hline Cert B20 & UDDS & 4.516 & 0.002 & 0.001 & 0.002 & 0.007 & 0.000 \\
\hline Cert B20 & UDDS & 4.113 & 0.002 & 0.000 & 0.001 & 0.005 & 0.001 \\
\hline CARB & UDDS & 6.085 & 0.004 & 0.002 & & 0.001 & \\
\hline CARB & UDDS & 6.337 & 0.003 & 0.002 & & 0.029 & \\
\hline CARB & UDDS & 5.701 & 0.004 & 0.002 & & 0.014 & \\
\hline CARB B20 & UDDS & 3.628 & 0.001 & 0.001 & & 0.004 & \\
\hline CARB B20 & UDDS & na & 0.001 & 0.001 & & 0.006 & \\
\hline CARB B20 & UDDS & 3.834 & 0.001 & 0.001 & & 0.004 & \\
\hline B100 & UDDS & & & & & & 0.001 \\
\hline B100 & UDDS & & & & & & 0.001 \\
\hline B100 & UDDS & & & & & & 0.002 \\
\hline
\end{tabular}


Table A6. Fuel Economy Results for All Tests.

\begin{tabular}{|c|c|c|c|c|c|c|c|}
\hline \multirow[b]{2}{*}{ Fuel } & \multirow[b]{2}{*}{ Cycle } & \multicolumn{6}{|c|}{ Bus Fuel Economy (mpg) } \\
\hline & & 1998 & 2005 & 2008 & $2008 \mathrm{H}$ & 2010 & 2011 \\
\hline Cert & MAN & 2.67 & 2.66 & 3.13 & 2.77 & 2.65 & 2.69 \\
\hline Cert & MAN & 2.62 & 2.65 & 3.15 & 2.78 & 2.61 & 2.72 \\
\hline Cert & MAN & 2.60 & 2.82 & 3.13 & 2.84 & 2.61 & 2.69 \\
\hline Cert B20 & MAN & 2.43 & 2.70 & 2.88 & 2.78 & 2.64 & 2.63 \\
\hline Cert B20 & MAN & 2.44 & 2.63 & 2.96 & 2.72 & 2.57 & 2.63 \\
\hline Cert B20 & MAN & 2.46 & 2.65 & 2.88 & 2.68 & 2.63 & 2.70 \\
\hline CARB & MAN & 2.43 & 2.67 & 3.20 & & 2.66 & \\
\hline CARB & MAN & 2.42 & 2.62 & 3.18 & & 2.69 & \\
\hline CARB & MAN & 2.47 & 2.67 & 3.26 & & 2.68 & \\
\hline CARB B20 & MAN & 2.48 & 2.70 & 3.09 & & 2.64 & \\
\hline CARB B20 & MAN & 2.48 & 2.75 & 3.09 & & 2.57 & \\
\hline CARB B20 & MAN & 2.49 & 2.74 & 3.10 & & 2.59 & \\
\hline B100 & MAN & & & & & 2.29 & \\
\hline B100 & MAN & & & & & 2.29 & \\
\hline B100 & MAN & & & & & 2.29 & \\
\hline Cert & ОСТА & 3.76 & 3.70 & 4.62 & 3.79 & 3.71 & \\
\hline Cert & ОСТА & 3.80 & 4.07 & 4.64 & 3.75 & 3.70 & \\
\hline Cert & ОСТА & 3.83 & 4.05 & 4.55 & 3.79 & 3.70 & \\
\hline Cert B20 & ОСТА & 3.77 & 4.13 & 4.31 & 3.70 & 3.70 & \\
\hline Cert B20 & ОСТА & 3.82 & 4.08 & 4.19 & 3.67 & 3.71 & \\
\hline Cert B20 & OCTA & 3.78 & 4.09 & 4.38 & 3.68 & 3.71 & \\
\hline CARB & OCTA & 3.82 & 3.95 & 4.63 & & 3.74 & \\
\hline CARB & OCTA & 3.80 & 3.95 & 4.64 & & 3.74 & \\
\hline CARB & OCTA & 3.81 & 3.96 & 4.66 & & 3.72 & \\
\hline CARB B20 & OCTA & 3.84 & 4.00 & 4.54 & & 3.27 & \\
\hline CARB B20 & OCTA & 3.83 & 3.97 & 4.22 & & 3.30 & \\
\hline CARB B20 & OCTA & 3.86 & 3.97 & 4.53 & & 3.29 & \\
\hline Cert & UDDS & na & 5.24 & 5.78 & 4.99 & 4.67 & 5.03 \\
\hline Cert & UDDS & 5.89 & 5.25 & 5.67 & 4.98 & 4.73 & 5.01 \\
\hline Cert & UDDS & 5.20 & 5.25 & 5.64 & 4.95 & 4.72 & 4.71 \\
\hline Cert B20 & UDDS & 5.47 & 4.98 & 5.76 & 4.73 & 4.78 & 4.88 \\
\hline Cert B20 & UDDS & 5.47 & 5.23 & 5.74 & 4.97 & 4.80 & 4.87 \\
\hline Cert B20 & UDDS & 5.47 & 5.15 & 5.75 & 4.87 & 4.84 & 4.89 \\
\hline CARB & UDDS & 5.41 & 5.29 & 5.97 & & 6.53 & \\
\hline CARB & UDDS & 5.41 & 5.30 & 5.95 & & 5.03 & \\
\hline CARB & UDDS & 5.43 & 5.30 & 5.81 & & 4.97 & \\
\hline CARB B20 & UDDS & 5.54 & 5.22 & 5.65 & & 4.78 & \\
\hline CARB B20 & UDDS & 5.50 & 5.06 & 5.89 & & 4.80 & \\
\hline CARB B20 & UDDS & 5.47 & 5.00 & 5.80 & & 4.79 & \\
\hline B100 & UDDS & & & & & & 4.54 \\
\hline B100 & UDDS & & & & & & 4.58 \\
\hline B100 & UDDS & & & & & & 4.55 \\
\hline
\end{tabular}

